\title{
ECLETICA
}

www.scielo.br/eq

Volume 30, número 3, 2005

\section{Fast determination of minoxidil by photometric flow titration}

\author{
R. A. de Sousa', F. S. Semaan², J. A. F. Baio², E. T. G. Cavalheiro ${ }^{2 *}$ \\ ${ }^{l}$ Departamento de Química, Universidade Federal de São Carlos, Rod. Washington Luiz Km 235 \\ , São Carlos, São Paulo, Brasil, CEP 13565-905, P O Box 676. \\ ${ }^{2}$ Departamento de Química e Física Molecular, Instituto de Química de São Carlos, Universidade de São Paulo, Av \\ Trabalhador Sãocarlense, 400, Centro, São Carlos, São Paulo, Brasil, CEP 13560-970, PO Box 780. \\ *Corresponding author:E-mail:cavalheiro@iqsc.usp.br
}

\begin{abstract}
A photometric flow titration based on the redox reaction between $\mathrm{KMnO}_{4}$ and minoxidil is described. The best titration results were observed at $3.20 \times 10^{-4} \mathrm{~mol} \mathrm{~L}^{-1} \mathrm{KMnO}_{4}$ and $1.00 \times 10^{-3} \mathrm{~mol} \mathrm{~L}^{-1}$ minoxidil, using the minoxidil solutions as titrant. The flow rate was fixed at $17 \mathrm{~mL} \mathrm{~min}^{-1}$ and the titrant was added to the system in aliquots of $500 \mu \mathrm{L}$, the color changes were monitored at $550 \mathrm{~nm}$. The method was applied to commercial samples and compared with the results from a chromatographic procedure. Recoveries from 97.6 to $102.8 \%$ were observed depending on the sample. Comparison with the chromatographic procedure reveled relative errors of $3.5-4.0 \%$.
\end{abstract}

Keywords: minoxidil determination; photometric titration; flow titration.

\section{Introduction}

Minoxidil(2,4-diamino-6-piperidinopyrimidine3-oxide, structure in Eq. 1) is an odorless white crystalline powder, insoluble in water, acetone or alkaline solutions, slightly soluble in alcohols, and freely soluble in acidic solutions [1].

Minoxidil has been used as a peripheral vasodilatator drug orally administrated, applied in the treatment of refractory hypertension patients [2]. Excessive oral administration of this drug to patient should cause liquid retention and hirsutism [3].

Initially described as an antihypertensive drug, minoxidil have also shown new applications in dermatology, especially in the treatment of androgenic alopecia [3,4]. In this case, this drug has been topically applied in order to stimulate hair growth by inducing vasodilatation and increasing the local irrigation and blood flow [4].

Commercially available products contain $2 \%$ minoxidil $\left(20 \mathrm{mg} \mathrm{mL}^{-1}\right)$, in topic use formulations, containing ethanol, and propylene glycol, or their mixture with 2-n-nonyl-1,3dioxolane as a vehicle $[5,6]$.

In acidic media and presence of reductors, minoxidil presents redox processes [2], but the oxidation reaction is not described and still being subject of investigation. Redox reactions have been used in order to determine several drugs. The principal applied oxidants are $\mathrm{IO}_{4}^{-}, \mathrm{BrO}_{3}^{-}, \mathrm{Cr}_{2} \mathrm{O}_{7}=$, among others [7].

In addition, several instrumental techniques have been described for minoxidil determination in matrixes such as serum and pharmaceutical products. Most of them are based in chromatographic methods as described in references $8-11$, as examples.

Ruiz-Medina et al. [3] developed an integrated flow injection system with solid phase extraction devices and photometric detection to determine minoxidil in tablets and solutions. In this case, minoxidil was concentrated on Sephadex SPC25 without need of derivatization.

Photometric titration consists in an experimental titration procedure in which the equivalence point is detected by a photometric 
detector [12]. This application provides more accurate results than direct (spectro) photometric determination, since the data of several measurements are pooled in order to determine the end point. This application has been used in the determination of biological molecules, drugs, metals, flocculants, etc [13 - 16].

When the sample under titration is continuously pumped from the titration vessel to the detector and then back the procedure is called flow photometric titration. In this mode of titration, aliquots of titrant are added to the system in order to produce the reaction. The solution is homogenized and carried to the detector by a continuous flow [17]. The addition of aliquots generates a dilution effect in the system, which can be minimized using suitably concentrated solutions preventing large volumes of titrant [17].

This work describes the development and application a simple and fast procedure, for the determination of minoxidil in pharmaceutical formulations, based on the discoloring redox reaction with $\mathrm{KMnO}_{4}$, used as self indicator. The reaction as well as the products are still under investigation.

\section{Experimental}

\section{Reagents and Solutions}

All the reagents were of analytical grade and used as received. Solutions were prepared using water bi-distilled in quartz stiller. Potassium permanganate (Merck, Germany) solutions were prepared by direct dissolution of the salt and standardized with sodium oxalate (Merck, Germany), in $\mathrm{H}_{2} \mathrm{SO}_{4} 2.00 \mathrm{~mol} \mathrm{~L}^{-1}$, as described elsewhere [18]. Minoxidil was from Natural Pharma (Brazil), and $\mathrm{H}_{2} \mathrm{SO}_{4}$ from Mallinckrodt (Mexico).

\section{Instruments}

The fluids were propelled with the help of a Ismatec IPC -8 peristaltic pump which provided a continuous flow. The tubbing were made by tygon and polyethylene tubing $(0.8 \mathrm{~mm})$. The photometric signals were monitored using a Genesis 20 (Thermospectronics, USA) spectrophotometer, at the wavelength $550 \mathrm{~nm}$. The experiments were carried out at $25^{\circ} \mathrm{C}$ under vigorous stirring provided by a magnetic stirring bar and a magnetic stirrer (Corning, USA).

\section{Commercial Samples}

The commercial samples used in this work were Regaine ${ }^{\circledast}$ from Pharmacia (USA) and Neoxidil ${ }^{\circledast}$ from Galderma (Brazil); purchased in the local market. Both samples were composed by topic solutions of minoxidil $2 \%\left(20 \mathrm{mg} \mathrm{mL}^{-1}\right)$ and a mixture of ethanol and propylene glycol as vehicle.

The samples were prepared by accurately transferring a suitable volume of each commercial product to a $50 \mathrm{~mL}$ volumetric flasks and the volumes completed with $\mathrm{H}_{2} \mathrm{SO}_{4} 2.00 \mathrm{~mol} \mathrm{~L}^{-1}$ in order to obtain a $1.00 \times 10^{-3} \mathrm{~mol} \mathrm{~L}^{-1}$ minoxidil solution, based on the label information.

\section{Titrimetric Procedure}

A $0,750 \mathrm{~mL}$ aliquot of an approximately 1.00 x $10^{-2} \mathrm{~mol} \mathrm{~L}^{-1} \mathrm{KMnO}_{4}$ solution, freshly prepared and standardized, were transferred to an erlenmeyer containing $25 \mathrm{~mL}$ of distilled water resulting in an approximately $3.00 \times 10^{-4} \mathrm{~mol} \mathrm{~L}^{-1} \mathrm{KMnO}_{4}$ solution, whose absorbance is close to 1.0 .

In order to provide an adequate reaction time the flow rate was adjust to a value close to $17 \mathrm{~mL}$ $\mathrm{min}^{-1}$. Increments of $500 \mu \mathrm{L}$ of prepared samples were added to the system until the twice the volume required to the end point.

\section{Results and discussion}

In order to determine the stoichiometric coefficient of the reaction between minoxidil and $\mathrm{KMnO}_{4}$, standard solutions of both reagents were titrated as described in the experimental section. The end points were determined by the interception of the straight lines in the titration plots. Such coefficient was determined as being 1.7, corresponding to $5 \mathrm{KMnO}_{4}: 3$ minoxidil. On the basis of this stoichiometric ratio a suggested redox reaction is proposed (Equation 1 and 2). The $\mathrm{N} \rightarrow \mathrm{O}$ bond is decomposed in acid media. 

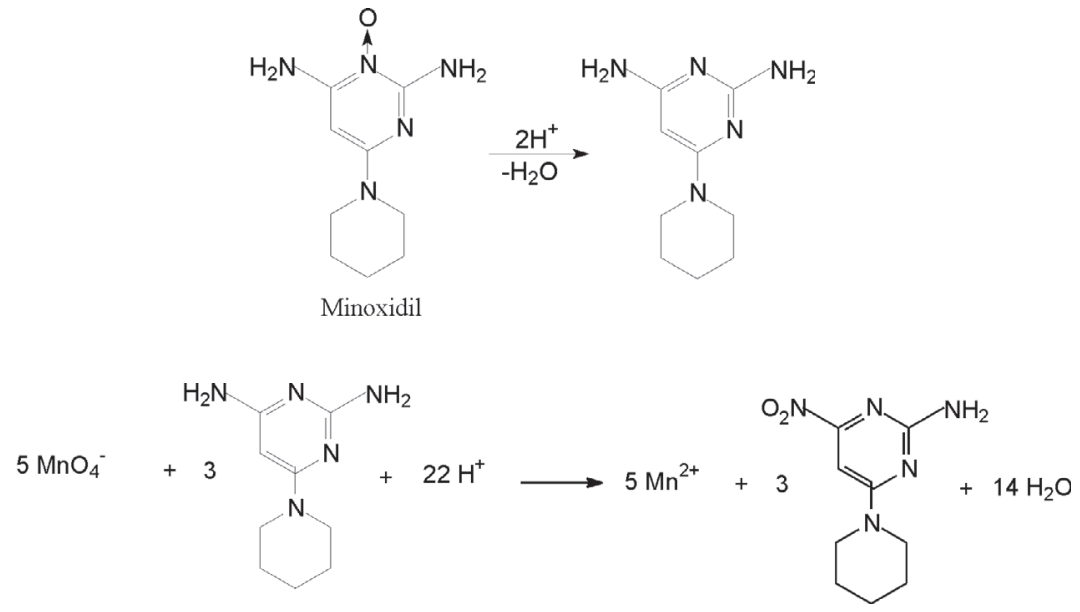

\section{Wavelength Selection}

The redox reaction between the minoxidil and $\mathrm{KMnO}_{4}$ in acidic media produces a colorless mixture. The reaction is not described and the products are not clearly elucidated. The $\mathrm{KMnO}_{4}$ solution exhibits absorption between 450 and 600 $\mathrm{nm}$, while minoxidil solution and commercial formulation do not absorbs in the visible region. In this way, the color changes during the titration could be photometrically accomplished at $550 \mathrm{~nm}$. Figure 1 presents the spectra of minoxidil, $\mathrm{KMnO}_{4}$, and titration products.

Sousa et al. Fig.1

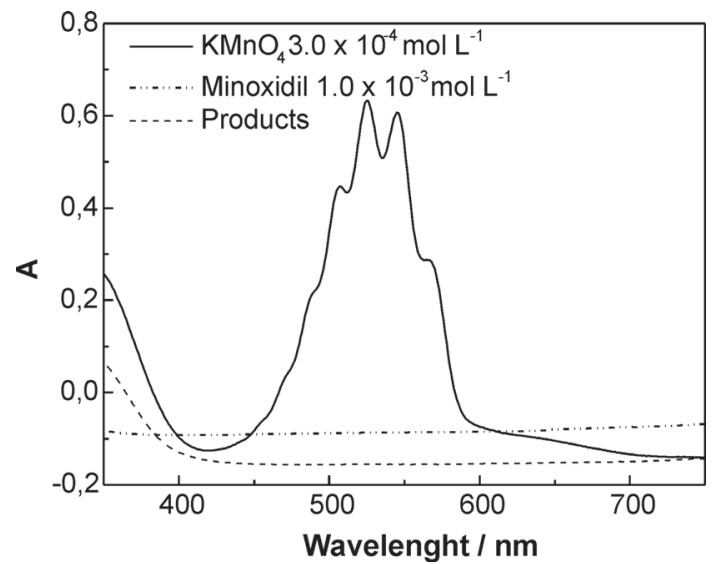

Figure 1. Absorption spectra of the reagents and products. $A$ is the absorbance of the solution.
The dilution effects on the absorbance were corrected according to Eq. $3[17,19]$ :

$$
\mathrm{A}_{\text {corrected }}=\mathrm{A}_{\text {read }}\left(\mathrm{V}_{0}+\mathrm{V}\right) / \mathrm{V}_{0}
$$

in which $\mathrm{V}_{0}$ is the initial volume and $\mathrm{V}$ is the volume of titrant added is each addition.

All absorbance measurements in this work were corrected by this equation, avoiding other mathematical treatment as described by Dyson et al. [20].

Optimization on Standard and Sample Concentrations

The optimization of the titration condition was started with the $\mathrm{KMnO}_{4}$ concentration, which was calculated in order to reach an initial signal close to 1.00. The absorbance vs $\mathrm{KMnO}_{4}$ concentration graph was investigated in the $4.00 \mathrm{x}$ $10^{-5}-3.20 \times 10^{-4} \mathrm{~mol} \mathrm{~L}^{-1} \mathrm{KMnO}_{4}$ concentration range, and the Lambert-Beer law was obeyed according the linear Equation 4.

$\mathrm{A}=3,092.0\left[\mathrm{KMnO}_{4}\right]+0.00751\left(\mathrm{n}=5, \mathrm{r}=0.9999_{9}\right)$

According to these results a working $3.20 \mathrm{x}$ $10^{-4} \mathrm{~mol} \mathrm{~L}^{-1} \mathrm{KMnO}_{4}$ solution was used at the starting of the titrations.

As the reagents concentration affect the sensitivity of the photometric titration procedure, then based on the linear range observed for $\mathrm{KMnO}_{4}$, 
a series of titrations was performed using $4.00 \times 10^{-}$ $5-3.20 \times 10^{-4} \mathrm{~mol} \mathrm{~L}^{-1}$ and $1.00 \times 10^{-3}-2.50 \times 10^{-4}$ $\mathrm{mol} \mathrm{L}^{-1} \mathrm{KMnO}_{4}$ and minoxidil solutions, respectively and the results are presented in Figure 2. In this Figure is possible to observe a remarked loss of sensibility that causes a difficult definition of the end point at low concentrations. According to these curves, the sets A and B are those that cause the most marked changes and could be used in these titrations.

Sousa et al. Fig.2

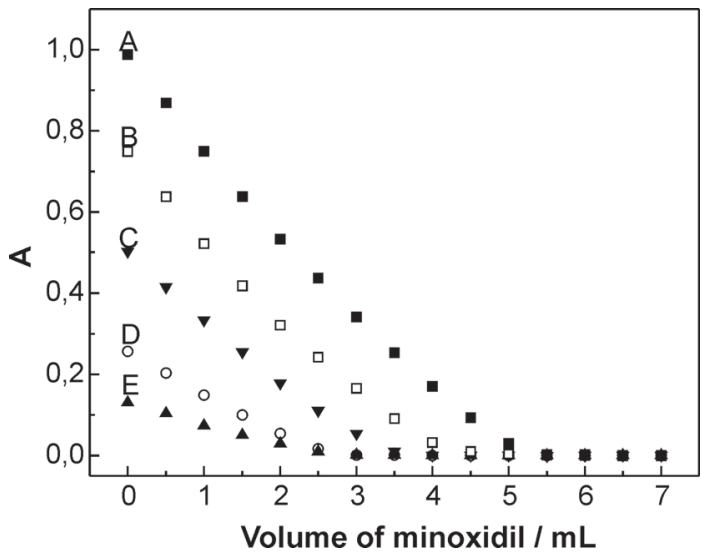

Figure 2. Optimization of minoxidil and $\mathrm{KMnO}_{4}$ concentration / $\mathrm{mol} \mathrm{L}^{-1}$.

A) minoxidil $1.00 \times 10^{-3} / \mathrm{KMnO}_{4} 3.20 \times 10^{-4}$; B) minoxidil $1.00 \times 10^{-3} / \mathrm{KMnO}_{4} 2.40 \times 10^{-4}$;

C) minoxidil $7.50 \times 10^{-4} / \mathrm{KMnO}_{4} 1.60 \times 10^{-4}$; D) minoxidil $5.00 \times 10^{-4} / \mathrm{KMnO}_{4} 8.00 \times 10^{-5}$;

E) minoxidil $2.50 \times 10^{-4} / \mathrm{KMnO}_{4} 4.00 \times 10^{-5}$.

\section{Sample Determinations}

The diluted samples were delivered from the burette and used to titrate $\mathrm{KMnO}_{4}$ solutions, while the solution color was monitored at $550 \mathrm{~nm}$.

Examples of the titrations of $\mathrm{KMnO}_{4}$ and standard minoxidil, regaine and neoxidil solutions under the optimized conditions are presented in Figure 3.

Table 1 presents the results obtained for the end points and content of minoxidil in the commercial samples in triplicate. In this case standard deviation of \pm 0.4 was observed in both cases (Table 2).
Sousa et al. Fig.3

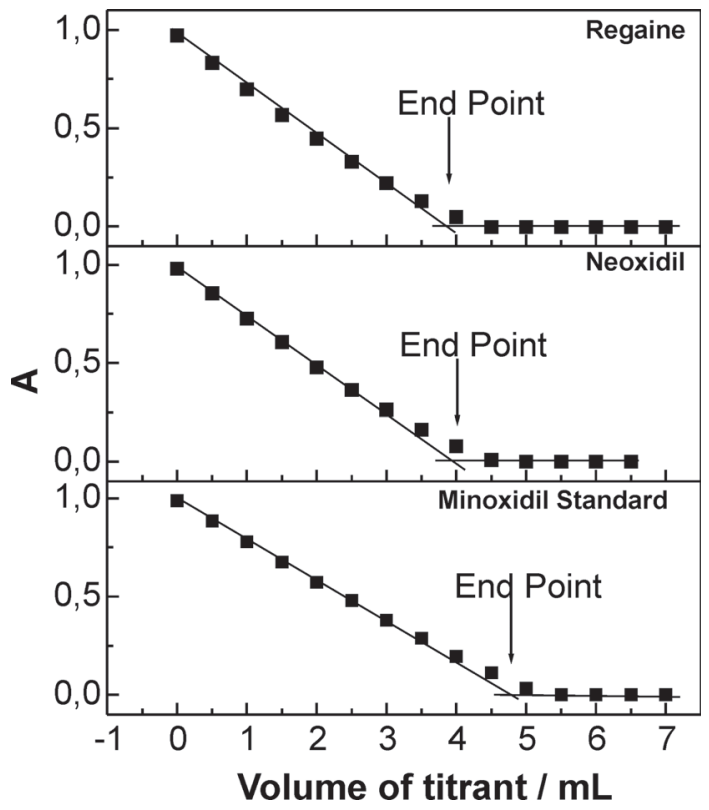

Figure 3. Examples of titration curves. The standard was $9.62 \times 10^{-4} \mathrm{~mol} \mathrm{~L}^{-1}$, Regaine ${ }^{\hat{a}}$ and Neoxidilâ were diluted to be $1.00 \times 10^{-3} \mathrm{~mol} \mathrm{~L}^{-1}$, according to the label value.

Recoveries from $97.6 \%$ to $102.8 \%$, and from $99.2 \%$ to $101 \%$ were found in the determination of spiked samples of Neoxidil ${ }^{\grave{2}}$ and Regaine $^{\grave{\partial}}$, respectively.

Since our goal was to determine minoxidil in the topic solutions a complete interference study was not performed. However we observed that the components of the vehicle of the formulations analysed in the present work (ethanol and propileneglicol) did not presented any effect in the determination.

\section{Comparison Method}

In order to check the accuracy of the proposed procedure the results were compared with those from a chromatography procedure describe by Zarghi et al. [8], which are presented in Table 2.

The t-test showed that the chromatographic results are in agreement with the proposed photometric method within a $95 \%$ confidence level. 
Table 1. End points of sample replicates and concentration found for two commercial minoxidil formulations

\begin{tabular}{|c|c|c|c|}
\hline Sample & Replicate & End point / mL & Found / $\mathrm{mg} \mathrm{mL}^{-1}$ \\
\hline \multirow[t]{4}{*}{ Neoxidil $^{\circledR}$} & 1 & 4.32 & 22.0 \\
\hline & 2 & 4.39 & 21.6 \\
\hline & 3 & 4.50 & 21.2 \\
\hline & & & mean $\pm \mathrm{sd}(\mathrm{n}=3)=21.2 \pm 0.4$ \\
\hline \multirow[t]{4}{*}{ Regaine $^{\circledR}$} & 1 & 4.34 & 21.8 \\
\hline & 2 & 4.32 & 22.0 \\
\hline & 3 & 4.48 & 21.2 \\
\hline & & & mean $\pm \mathrm{sd}(\mathrm{n}=3)=21.7 \pm 0.4$ \\
\hline
\end{tabular}

Table 2: Comparison between labeled and found minoxidil contents / $\mathrm{mg} \mathrm{mL}^{-1}$

\begin{tabular}{ccccc}
\hline Sample & Labeled & ${\text { Comparison method }[8]^{\text {a }}}$ & Found $^{\mathrm{b}}$ & Error $^{\mathrm{d}} / \mathbf{\%}$ \\
\hline Neoxidil $^{\circledR}$ & 20 & 20.8 & $21.6 \pm 0.4^{\mathrm{c}}$ & 3.8 \\
Regaine $^{\circledR}$ & 20 & 21.0 & $21.7 \pm 0.4^{\mathrm{c}}$ & 3.3 \\
\hline
\end{tabular}

${ }^{\mathrm{a}} \mathrm{n}=1$

${ }^{\mathrm{b}} \mathrm{n}=3$

${ }^{c}$ standard deviation

${ }^{\mathrm{d}}[$ (found - comparison)/comparison $] * 100$

\section{Conclusions}

In this work a new method for minoxidil determination was developed. This new procedure consists in a continuous flow photometric titration based on the reaction between $\mathrm{KMnO}_{4}$ and the analyte, based in $\mathrm{KMnO}_{4}$ discoloring redox reaction.

Best conditions were reached when the concentrations of $\mathrm{KMnO}_{4}$ and minoxidil were fixed at $3.20 \times 10^{-4} \mathrm{~mol} \mathrm{~L}^{1}$ and $1.00 \times 10^{-3} \mathrm{~mol} \mathrm{~L}^{-1}$, respectively.

The sample preparation procedure used acidic media (according to Reference 1), obeying the physical solubility properties of minoxidil. This procedure avoided the use of organic compounds, turning the proposed method safer and cheaper than chromatographic ones. The proposed method consumes less reagent and time than the others, described in literature can be an alternative to determine minoxidil in commercial samples in a fast, low expensive, easy and generating low residue amounts.

\section{Aknowledgements}

The authors are grateful to Brazilian agencies CAPES and CNPq for RAS and ETGC fellowships, and FAPESP for the fellowship to FSS (proc. 04/ 08550-0) and research support (proc. 04/00407-4).

Recebido em: 27/06/2005

Aceito em: 23/08/2005 
R. A. de Sousa, F. S. Semaan, J. A. F. Baio, E. T. G. Cavalheiro. Determinação rápida de minoxidil usando titulação fotométrica

Resumo: Um procedimento fotométrico em fluxo contínuo, baseado na reação de óxido-redução entre $\mathrm{KMnO}_{4}$ e minoxidil é proposto. Os melhores resultados na titulação foram obtidos usando concentrações de permanganato de $3,20 \times 10^{-4} \mathrm{~mol} \mathrm{~L}^{-1}$ e minoxidil, usado como titulante, da ordem de $1,00 \times 10^{-3} \mathrm{~mol} \mathrm{~L}^{-1}$. Vazão de $17 \mathrm{~mL} \mathrm{~min}^{-1}$ foi fixada para as leituras fotométricas contínuas e o titulante foi adicionado em alíquotas de $500 \mu \mathrm{L}$, enquanto as mudanças de cor foram monitoradas em $550 \mathrm{~nm}$. Recuperações da ordem de 97,6 a 102,8\% foram observadas, dependo da amostra analisada. O método foi aplicado a amostras comerciais contendo minoxidil e comparado com resultados obtidos a partir de procedimentos cromatográficos com erros relativos da ordem de 3,5 a 4,0\%.

Palavras-chave: determinação de minoxidil; titulação fotométrica; titulação em fluxo.

\section{References}

[1] S. S. Budavari, M.J. O’Neil, A. Smith, P.E. Heckelman, J.F. Kinneary, The Merck Index, $13^{\text {th }}$, Merck \& Company Incorporated, Whitehouse Station, New Jersey, 2001, 6229 p.

[2] L. Amankwa, L. G. Chatten, S. Pons, Analyst, 108 (1983) 1221.

[3] A. R. Medina, M. L. F. Córdova, A. Molina-Díaz, Talanta, 50 (1999) 277.

[4]J. H. Han, O. S. Kwon, J. H. Chung, K. H. Cho, H. C. Eun, K. H. Kim, J. Dermatol. Sci., 34 (2004) 91.

[5] W. Z. Zhong, P. E. Sanders, M. J. Hauer, J. J. Vrbanae, J. Chromatogr. B, 705 (1998) 39.

[6] W. Z. Zhong, J. Pharm. Biomed. Anal., 16 (1998) 1179.

[7] W. Misiuk, H. Puzanowska-Tarasiewics, Anal. Lett., 35 (2002) 1163.

[8] A. Zarghi, M. Jenabi, A. J. Ebrahimian, Pharm. Acta Helvet., 73 (1998) 163.

[9] S. Fanali, M.Cristalli.; P. Catellani, J. Chromatogr. A, 405 (1987) 385.

[10] G. Carrum, D.R. Abernethy, M.S.C.E. Wright, J. Chromatogr. B, 381 (1986) 127.
[11] A. Zarghi, A. Shafaati, S.M. Foroutan, A. Hoddam, J. Pharm. Biomed. Anal., 36 (2004) 377.

[12] D. A. Skoog, D. M. West, F. J. Hooler, Fundamentals of Analytical Chemistry, $7^{\text {th }}$ edn, Saunders College Publishing, Philadelphia, 1996, p.581.

[13] Z. Liang, C. Bonneville, T. Senez, T. Henderson, J. Pharm. Biomed. Anal., 28 (2002) 245.

[14] P. J. Fletcher, J. F. Van-Staden, Anal. Chimica Acta, 485 (2003) 187.

[15] R. S. Honorato, E. A. G. Zagatto, R. A. C. Lima, M. C. U. Araújo, Anal. Chim. Acta, 416 (2000) 231.

[16] T. Masadome, Talanta, 59 (2003) 659.

[17] L. Sommer, Analytical absorption spectrophotometry in the visible and ultraviolet - The Principles, Elsevier, Budapeste, 1989 , p.311.

[18] G.D. Christian, Analytical Chemistry, $5^{\text {th }}$ edn, Wiley \& Sons, New York, 1994, p.365.

[19]D. C. Harris, Análise Química Quantitativa, $5^{\text {th }}$ edn, LTC, Rio de Janeiro, 2001, p.130.

[20]R. M. Dyson, P. Jandanklang, M. Maeder, C. J. Mason, A. Whitson, Polyhedron, 18 (1999) 3227. 